\title{
Risk Factors of Healthcare-associated Infections Among Pediatric Hospitalized Patients in Chinese General Hospitals From 2001 to 2020: A Systematic Review and Meta-Analysis
}

\section{Danfeng Ye}

Songyang People's Hospital

\section{Lifang Cao}

Huzhou Traditional Chinese Medicine Hospital, Zhejiang University of Traditional Chinese Medicine

Xinliang Liu

the University of Manchester

Chaogang Yuan (D 577726885@qq.com)

Huzhou Traditional Chinese Medicine Hospital, Zhejiang University of Traditional Chinese Medicine

\section{Research Article}

Keywords: Healthcare-associated infections, Risk factors, Paediatric hospitalized patients, General hospitals, China, Systematic review and meta-analysis

Posted Date: September 27th, 2021

DOl: https://doi.org/10.21203/rs.3.rs-850550/v1

License: (1) (i) This work is licensed under a Creative Commons Attribution 4.0 International License. Read Full License 


\section{Abstract}

Background: Healthcare-associated infections (HAls) have been an increasing global public health threat to the globe. Paediatric hospitalized patients are particularly to HAls and the identification of risk factors is essential to help policy-makers and hospital managers to develop prevention and control strategies. This study aims to determine the risk factors associated with HAls among paediatric hospitalized patients in Chinese general hospitals.

Methods: Medline, EMBASE and Chinese Journals Online databases were searched. The search was limited to studies published from January $1^{\text {st }} 2001$ and December $31^{\text {st }} 2020$. Meta-analyses of OR in the prevalence were estimated. Heterogeneity between studies was assessed based on the $\mathrm{B}^{2}$ and $P$ statistics to select the meta-analysis model. Reviewer Manager 5.3 was employed and $P<0.05$ was considered as the statistical significance.

Results: 205 published articled were searched from the databases, in which 25 studies were included in the quantitative synthesis and meta-analysis for the risk factors of HAls among paediatric hospitalized patients in Chinese general hospitals. 61,773 paediatric patients were incorporated in the included studies, which covered 13 regions in 10 provinces in China. Of them, 2,438 paediatric patients had HAls. The meta-analyses showed that the ORs of younger age(2.25[1.32-3.85]), hormone(3.66[1.73-7.74]), invasive procedures(5.62[4.27-7.40]), longer hospitalization stay (7.79[6.38-9.50]), malnutrition(3.72,[1.80-7.70]), over 3 kinds of antibiotics (3.25,[2.66-3.96]), over 3 kinds of underlying disease (4.24[1.84-9.78]), large room (2.22[1.28-3.85)), and autumns and winter (1.56[1.04-2.35)) were the independent risk factors that had a negative impact on HAls with a statistical significance $(P<0.05)$.

Conclusions: Under the age of 1 year, application of hormone, experiencing invasive procedure, hospitalization stay more than 7 days, malnutrition, using more than 3 kinds of antibiotics, beyond 3 kinds of underlying disease, large room, and autumn and winter were the main risk factors associated with the higher prevalence of HAls among paediatric hospitalized patients in Chinese general hospitals. This provided the evidence base to inform the policy-makers and hospital managers. The confirmed successful and costeffective prevention and control measures need to be adopted to reduce the occurrence of HAls.

\section{Introduction}

Healthcare-associated infections (HAls) have been an increasing global public health threat to the globe, taking place in a hospital setting after patients are admitted to the hospital more than 48 hours $(1,2)$. Evidence has shown that HAls have not only increased the mortality, morbidity and prolonged hospitalization for the patients, especially when the antimicrobial resistant microorganisms caused HAls, but also led to high economic burden for the whole society $(3,4)$. China is certainly affected by HAls and has reported that HAls could result in the direct economic burden around $¥ 10$ to 15 billion (5). Besides, a study conducted in 68 Chinese hospitals estimated that HAls increased the hospitalization stay of 10.4 days (6). It is essential to take cost effective measures to reduce the presence of HAls, such as the surveillance system of HAls and China has established the National Nosocomial Infection Surveillance System. 
As the increasing number of the special susceptible populations, paediatric hospitalized patients are particularly vulnerable to HAls, due to their internal characteristics and external factors such as immature immune systems, immuno-deficiencies, total parenteral nutrition, congenital malformations, and stay in an intensive care $(\mathrm{ICU})(7,8)$. A study undertaken in the developing countries showed that the incidence of HAls in neonate intensive care (NICU) is nearly $30 \%$ and is responsible for $4-56 \%$ of all causes of reported neonatal deaths $(9,10)$. Specially, the prevalence of HAls was reported with a range from 10 to $25 \%$ in paediatric intensive care (PICU) in China $(11,12)$.

Current literature has confirmed that up to $70 \%$ of HAls cases could be preventable $(13,14)$. This shows that the identification of the risk factors on HAls is essential to help the policy-makers and hospital managers to develop the prevention and control strategies and allocate the relevant resources to protect the susceptible hospitalized patients, resulting in the reduction on the occurrence of HAls (15). However, limited risk factor analysis studies on HAls among paediatric hospitalized patients have been conducted only in individual hospitals and no comprehensive study is yet to be undertaken in China. Therefore, our systematic review and meta-analysis aims to determine the risk factors associated with HAls among paediatric hospitalized patients in Chinese general hospitals, which are different from specialty hospitals.

\section{Methodology}

\section{Systematic search strategy}

The PICO/S (Population, Intervention, Comparison, Outcome, and Study type) tool was applied to define the scope of the literature. The specific details are as follows.

Population: paediatric hospitalized patients admitted to the hospitals more than $48 \mathrm{hrs}$

Intervention: healthcare-associated infections diagnosed by the criteria reported by the Chinese National Nosocomial Infections Surveillance System

Comparison: paediatric hospitalized patients without healthcare-associated infections

Outcome: HAls prevalence

Study type: cross-sectional study, case-control study or cohort study

This systematic review and meta-analysis was conducted based on the Preferred Reporting Items for Systematic Reviews and Meta-analysis (PRISMA) guidelines. Medline, EMBASE and Chinese Journals Online databases (China National Knowledge Infrastructure [CNKI], Chinese Wan Fang digital database and Chinese Science and Technique Journals Database [VIP]) were selected to search the relevant literature. The studies published were limited between 1st January 2001 and 31st December 2020.

Chinese corresponding search terms in the title, abstract and keywords included healthcare-associated infections/cross infections/hospital acquired infections/nosocomial infections, risk factors/influencing factors, paediatric department/children/adolescent and China for the Chinese databases (CNKI, Wan Fang, 
and VIP ). As to Medline and EMBASE, the medical subject heading (MeSH) terms in keywords were adopted, including "cross infection" AND "risk factors" AND "paediatrics" OR "children" OR "adolescent" OR "child" OR "paediatrics" AND "China".

\section{Inclusion and exclusion criteria}

The inclusion criteria were as follows: 1) risk factors analysis with a case-control, cohort or cross-sectional study; 2) a multi-centre study or a single-centre study; 3) study language being either English or Chinese; 4) general hospital(s) (non-speciality hospitals); 5) any study published between 1st January 2001 and 31st December 2020.

The exclusion criteria were as follows: 1) conference papers or editorials/letters; 2) duplicate studies and repeated data published in different journals or in theses and journals concomitantly; 3 ) any study outside China; 4) any study reporting only on specific hospital units rather than overall hospital setting (e.g. neurosurgery) or disease (e.g. pneumonia) or infection type (e.g. ventilator-associated pneumonia); 5) only description on the prevalence or landscape of HAls; 6 ) risk factors concluded without any statistical inference (e.g. only description or summary) and only based on the researchers' perspective.

\section{Data abstraction}

Three independent reviewers (D.Y., L. C. and X.L.) searched the relevant published articles on risk factors for HAls among paediatric hospitalized patients from the included databases. Initial screening of the searched published articles was conducted by screening the titles, abstracts and keywords. The eligibility for the articles was scrutinized by reading the full text according to the inclusion and exclusion criteria. The eligibility for $10 \%$ of the included studies screened by each reviewer was checked again by other two reviewers to determine whether it was appropriate. Disagreement on the included studies was dealt with based on the discussion within the three reviewers.

\section{Quality assessment}

The JBI' (Joanna Briggs Institute) critical appraisal tools were employed to assess the quality of the included studies conducted by the three reviewers (D.Y., L. C. and X.L.) (16). This tool includes 8 questions to identify the quality of a cross-sectional study, 10 questions to determine the quality of a case-control study, and 11 questions to assess the quality of a cohort study. For each question, there are 4 options to choose (Yes, Unclear, No and Not applicable). The less the number of a positive option (Yes) is, the more the uncertainty of a study is. Otherwise, the quality of a study is better. Besides, 0-2 points were assigned to each question. That is, 'Yes' is equal to 2 points; 'Unclear or Not applicable' is equal to 1 point; and 'No' is equal to 0. Therefore, the higher scores of a study get, the better quality of this study is.

\section{Statistical analysis}

Review Manager 5.3 software was deployed to estimate the risk factor odds ratio (OR) to show the level of risk that each factor between the HAls pediatric hospitalized patients and the pediatric hospitalized patients without HAls. Moreover, the forest plot was applied to show the results of the pooled OR of each risk factor. Heterogeneity between studies was assessed based on the $\hat{t}^{2}$ and $R$ statistics to select the meta-analysis model. When results had a $\hat{\tau}^{2}(P \leq 0.05)$ and/or $P>50 \%$, data were considered heterogeneous and the 
random-effects model was used; otherwise, the fixed-effects model was used. $P<0.05$ was set as the statistical significance.

\section{Results}

Characteristics of the eligible studies from the database search

Figure 1 exhibits that generally, 205 published articles were screened from the database search. After screening the full text with the inclusion and exclusion criteria, 15 publications were included in the quantitative synthesis and meta-analysis for the risk factors associated with the HAls prevalence among paediatric hospitalized patients.

Table 1 presents that totally, 61,773 paediatric hospitalized patients were included in the 15 included studies, which covered 13 regions in 10 provinces of China. Specifically, 2,438 patients were identified as having HAls, while 59,335 patients did not have HAls. The majority (11/15) of the included studies were retrospective cross-sectional studies; 2 studies were retrospective case-control studies; one was retrospective cohort study; and one was retrospective and prospective study. Besides, most of the studies (9/15) were conducted in tertiary hospitals, while the rest were undertaken in secondary hospitals.

\section{Frequency of the identified risk factors from the included studies}

Table 2 shows a total of 20 risk factors on HAls were identified from the 15 included studies. The most frequent risk factors were length of hospitalization (14/15), age (10/15), gender (5/15) and number of kinds of antibiotics use (5/15). The risk factors were not incorporated in the meta-analyses since the frequency was less than 2. In addition, although the classification of the age and length of hospitalization was different among the included studies, we adopted the most frequent classification used in the included studies for the meta-analyses. With regard to the length of time of antibiotics use, due to the inconsistent classification used in both studies $(17,18)$, it was also excluded in the meta-analysis.

\section{Quality assessment of all the included studies}

With regard to the 13 cross-sectional studies, the median points were 10 (medium points). It indicated the overall quality of the cross-sectional studies was fair, which needed to be improved. All of the studies clearly defined the inclusion for the pediatric hospitalized patients and set the outcomes measured in a valid and reliable way. However, some of the cross-sectional studies needed to be improved in study design, including describing the study setting in more detail, providing the specific definition and inclusion and exclusion criteria for the HAls pediatric hospitalized patients etc. Only two case-control and one cohort studies were included in this systematic review. The overall quality of the case-control studies was good since one study got 17 points, while the other study got 18 points. Both of them also needed to provide the clear information about the outcome measurements and how to measure the exposure. The quality of the cohort study was poor (10 points). It did not clearly depict the follow-up time and how to deal with the incomplete follow-up. Also, it did not provide the clear information about the outcome measurements and how to measure the exposure. Quality assessments of the included studies are exhibited in Supplementary material (Appendix 1: Table 1, 2, and 3). 
Table 3 presents the pooled ORs of the risk factors estimated in the meta-analyses between the paediatric hospitalized patients with HAls and the paediatric hospitalized patients without HAls. 11 risk factors were analysed in the meta-analysis. Specific information is as follows. The forest plots of the included risk factors are shown in Supplementary material (Appendix 2: Figure 1-1 to 1-11).

Age ( $\leq 1$ year vs. $>1$ year): 6 studies $(17,19-23)$ reported the age ( $\leq 1$ year) of 429 with and 6,001 patients without HAls. The random-effects model showed that the prevalence of HAls was significantly higher $(P=0.003)$ in patients who were younger than 1 year old compared with those who were over 1 year old (OR: $2.25,95 \% \mathrm{Cl}: 1.32-3.85)$. There was a high heterogeneity among the studies $\left({ }^{2}=0.35(P<0.01), P^{2}=84 \%\right)$.

Gender (Male vs. Female): 6 studies $(17-19,22,24,25)$ reported the gender of 790 with and 15,289 patients without HAls. The fixed-effects model showed that the prevalence of HAls was almost equal $(P=0.26)$ between male and female patients (OR: 1.07, 95\% Cl: 0.95-1.21). The heterogeneity did not exist among the studies $\left(P=0.63, R^{2}=0 \%\right)$.

Hormone:2 studies $(17,18)$ reported the hormone of 25 with and 31 patients without HAls. The fixed-effects model showed that the prevalence of HAls was significantly higher $(P=0.0007)$ in patients using hormone than those not using hormone (OR: 3.66, 95\% Cl: 1.73-7.74). The heterogeneity did not exist among the studies $\left(P=0.61, P^{2}=0 \%\right)$.

Invasive procedures: 4 studies $(17,21,26,27)$ reported the invasive procedures of 191 with and 1,183 patients without HAls. The fixed-effects model showed that the prevalence of HAls was significantly higher $(P<0.01)$ in patients experiencing invasive procedure than those not experiencing invasive procedure (OR: $5.62,95 \% \mathrm{Cl}: 4.27-7.40)$. The heterogeneity did not exist among the studies $\left(P=0.77, P^{2}=0 \%\right)$.

Length of hospitalization ( $>7$ days vs. $\leq 7$ days): 12 studies $(17,19-25,28-31$ ) reported the length of hospitalization ( $>7$ days) of 1,617 with and 12,534 patients without HAls. The random-effects model showed that the prevalence of HAls was significantly higher $(P<0.01)$ in patients whose hospitalization were more than 7 days than those whose hospitalization were less than 7 days (OR: 7.79, 95\% Cl: 6.38-9.50). There was a middle level of heterogeneity among the studies $(2=0.06(P=0.001), P=64 \%)$.

Malnutrition:2 studies $(17,18)$ reported the malnutrition of 29 with and 54 patients without HAls. Fixedeffects model showed that the prevalence of HAls was significantly higher $(P=0.0004)$ in patients with malnutrition than those without malnutrition (OR: $3.72,95 \% \mathrm{Cl}: 1.80-7.70)$. The heterogeneity did not exist among the studies $\left(P=0.75, R^{2}=0 \%\right)$.

Number of kinds of antibiotics (>3 vs. $\leq 3)$ : 6 studies $(17,18,20,22,28,31)$ reported the number of kinds of antibiotics $(>3)$ of 177 with and 1,206 patients without HAls. The fixed-effects model showed that the prevalence of HAls was significantly higher $(P<0.01)$ in patients who used more than 3 kinds of antibiotics than those who used at most 3 kinds of antibiotics (OR: 3.25, 95\% Cl: 2.66-3.96). The heterogeneity did not exist among the studies $(P=0.15, P=39 \%)$. 
Number of underlying disease (>3 vs. $\leq 3)$ : 4 studies $(17,21,31)$ reported the number of underlying disease $(>3)$ of 68 with and 79 patients without HAls. The random-effects model showed that the prevalence of HAls was significantly higher $(P=0.0002)$ in patients who had more than 3 kinds of underlying disease than those who had at most 3 kinds of underlying disease (OR: 4.24, 95\% Cl: 1.84-9.78). The heterogeneity existed among the studies $\left({ }^{2}=0.30(P=0.11), P^{2}=55 \%\right)$.

Room size (Large vs. Small): 2 studies $(19,23)$ reported the room size (Big) of 77 with and 1,061 patients without HAls. Fixed-effects model showed that the prevalence of HAls was significantly higher $(P=0.005)$ in patients who stayed in a large room than those who stayed in a small room (OR: 2.22, 95\% Cl: 1.28-3.85). The heterogeneity did not exist among the studies $(P=0.72, R=0 \%)$.

Seasons (Autumn + Winter vs. Spring + Summer): 4 studies $(19,20,23,32)$ reported the seasons (Autumn + Winter) of 235 with and 6,145 patients without HAls. Random-effects model showed that the prevalence of HAls was significantly higher $(P=0.03)$ in patients who were admitted to the hospitals in autumn or winter than those who were admitted to the hospitals in spring or summer (OR: $1.56,95 \% \mathrm{Cl}: 1.04-2.35$ ). The heterogeneity existed among the studies $\left({ }^{2}=0.11(P=0.02), l^{2}=69 \%\right)$.

Use of antibiotics: 6 studies $(20,22,24,26,28,31)$ reported the use of antibiotics of 788 with and 20,957 patients without HAls. Random-effects model showed that the prevalence of HAls was higher $(P=0.09)$ in patients using antibiotics than those not using antibiotics (OR: 3.18, 95\% Cl: 0.83-12.15). There was a high heterogeneity among the studies $\left({ }^{2}=1.87(P<0.01), l^{2}=85 \%\right)$.

\section{Discussion}

Our systematic review and meta-analysis first provided the pooled ORs of the risk factors associated with the higher HAls prevalence among the paediatric hospitalized patients in Chinese general hospitals, which covered 61,773 paediatric hospitalized patients were included in the 15 included studies distributing 13 regions in 10 provinces of China. Of them, 2,438 patients were identified as having HAls. Besides, our study shows that age, gender, hormone, invasive procedures, length of hospitalization, malnutrition, number of kinds of antibiotics, number of underlying disease, room size, and seasons were the independent risk factors associated with the higher HAls prevalence among the paediatric hospitalized patients with a statistical significance $(P<0.05)$. Our findings could provide the evidence bases to develop the personalised prevention and control measures to reduce the HAls occurrence among paediatric hospitalized patients in China.

Our review found that paediatric hospitalized patients under the age of 1 year were at higher risk to get HAls than those beyond the age of 1 year. This is similar to another study carried out in Pennsylvania among paediatric healthcare-associated pneumonia, which showed that children who were younger than 1 year were the most cases $(33,34)$. Among the children patients below the age of 1 year, particularly the neonates (age $\leq 30$ days), due to the increasing number of low weight children, preterm infants, and critically ill children, they are more hazardous to acquire HAls, especially those in NICU (35). Jansen et al. recommended that human milk feeding is one of the cost effective measures to reduce the likelihood of getting HAls, because human milk feeding contains numerous substances and bioactive compounds with putative antimicrobial 
actions, thus decreasing the risk of acquiring HAls (1). Furthermore, the neonates should be set as the particular high-risk patients given special protective measures.

Application of hormone, malnutrition, and presence of more than 3 kinds of underlying disease among paediatric hospitalized patients was found as main risk factors for acquiring HAls in our review. Although hormone, especially glucocorticoid, could resist virus, inflammation, and allergy and so on, the long-term use of hormone severely impairs the children's growth and development, and internal secretion, thus increasing the chance of getting HAls (21). Nutrition is one of the ways to build up the children's immune systems, thereby increasing the resistance to HAls (36). However, the underlying disease increases the susceptibility of paediatric hospitalized patients, so that they are more prone to getting secondary infections due to the reduction of the patients' immune response $(3,37)$.

Our review also found that paediatric hospitalized patients with invasive procedure were over 5 times more hazardous to obtain HAls than their counterparts. Many studies have reported that invasive procedure, such as surgery, mechanical ventilation, and central venous catheter and so on increased the risk of obtaining HAls among paediatric hospitalized patients $(11,38)$. The hazard of getting HAls among paediatric hospitalized patients staying in hospital more than 7 days was over 7 times higher than their counterparts. This finding is consistent to the current literature $(3,11)$. The prolonged hospitalization stay increases the likelihood of acquiring HAls, whereas the presence of HAls also extends the hospitalization stay, which is a positive association (23). This further aggravates the difficulty of treatment of the disease and augments the medical expenditure.

The risk of acquiring HAls in paediatric hospitalized patients who used more than 3 kinds of antibiotics were over 3 times higher than those using less than 3 kinds of antibiotics, which is consistent with the study conducted among paediatric hospitalized patients with multi-drug resistant infection in PICU (11). Multiple varieties of antibiotics applied in paediatric hospitalized patients change the children's physiology and biochemistry, leading to weakening the children's immune system to the bacteria $(11,39)$. This can increase the risk of obtaining HAls. The United States has acknowledged that the antimicrobial treatment is the most sensitive proxy indicator for the presence of HAls (40). This indicates that the clinical doctors need to be prudent when giving antibiotics prescription to the paediatric hospitalized patients. Overuse of antibiotics is associated with the presence of antimicrobial resistance (AMR), which further impairs the patients' safety (4).

Paediatric hospitalized patients staying in a large inward and admitted to the hospitals in autumn or winter were more likely to acquire HAls than their counterparts suggested by our review. On one hand, children need to be cared for by their parents or guardians when they are in hospital, which results in quite frequent visits, especially in a large paediatric room (23). Therefore, this leads to increasing the occurrence of cross infection. Frequent disinfection based on the perfect execution, decreasing visits to the wards and effective isolation measures are necessary for the reduction of HAl among paediatric hospitalized patients. On the other hand, healthcare-associated respiratory infections are the most common HAls in paediatric inwards, which happens more frequently in autumn and winter. Therefore, it is essential to contain HAls in autumn and winter. 
After completing the identification of the risk factors associated with higher HAls prevalence among paediatric hospitalized patients, it is necessary to adopt corresponding prevention and control measures to reduce the occurrence of HAls, thus decreasing the mortality, morbidity and economic burden for patients and the whole society. Generally, a number of evidence-based prevention and control measures are recommended in current studies and have been confirmed successful (1). For example, washing hands is supposed to be the easiest cost-effective measure to decrease the risk of HAls. Jansen et al. have recently suggested that quality improvement on cooperation and benchmarking is most promising for reduction in HAls. Identifying and implementing the best practices, and selecting the quantitative measurements are two of the examples recommended in this study (1).

Our systematic review and meta-analysis has some limitations as well. First, our systematic review only included the Chinese general hospitals. Other types of hospitals, like speciality hospitals were excluded. Therefore, the whole picture of the risk factors for HAls among paediatric hospitalized patients in China is not yet to be shown in this review. Second, present included studies lack quality in study design. It calls for a more comprehensive study design to conduct the similar study in the future in China.

\section{Conclusions}

Under the age of 1 year, application of hormone, experiencing invasive procedure, hospitalization stay longer than 7 days, malnutrition, using more than 3 kinds of antibiotics, beyond 3 kinds of underlying disease, large room, and autumn and winter were the main risk factors associated with the higher prevalence of HAls among paediatric hospitalized patients in Chinese general hospitals. This provided the evidence base to inform the policy-makers and hospital managers when developing prevention and control strategies. The confirmed successful and cost-effective prevention and control measures need to be adopted to reduce the occurrence of HAls.

\section{Declarations}

\section{Ethics approval and consent to participate}

It is not applicable.

\section{Consent for publication}

It is not applicable.

\section{Availability of data and materials}

The datasets and materials analysed during the current study are available from the corresponding author on reasonable request.

\section{Competing interests}


The author(s) declared no potential conflicts of interest with respect to the research, authorship, and/or publication of this article.

\section{Funding}

It is not applicable.

\section{Authors' contributions}

C.Y. was in charge of the whole systematic review and meta-analysis. D.Y., L. C. and X.L. searched the relevant published articles from the databases and determined the quality of the included studies. D.Y., L. C. and C.Y. designed the systematic review framework. D.Y., L. C. and C.Y. drafted and revised the review manuscript. X.L. provided the comments to the manuscript and proofed the manuscript.

\section{References}

1. Jansen SJ, Lopriore E, van der Beek MT, Veldkamp KE, Steggerda SJ, Bekker V. The road to zero nosocomial infections in neonates-a narrative review. Acta Paediatrica. 2021;110(8):2326-35.

2. Arif S, Sadeeqa S, Saleem Z, Latif S, Sharif M. The burden of healthcare-associated infections among pediatrics: a repeated point prevalence survey from Pakistan. Hospital practice (1995). 2021;49(1):3440.

3. Sahiledengle B, Seyoum F, Abebe D, Geleta EN, Negash G, Kalu A, et al. Incidence and risk factors for hospital-acquired infection among paediatric patients in a teaching hospital: a prospective study in southeast Ethiopia. BMJ open. 2020;10(12):e037997.

4. Liu X, Cui D, Li H, Wang Q, Mao Z, Fang L, et al. Direct medical burden of antimicrobial-resistant healthcare-associated infections: empirical evidence from China. Journal of Hospital Infection. 2020;105(2):295-305.

5. Li L. Nosocomial Infection Management (in Chinese). Beijing: Peking University Medical Press2010.

6. Jia H, Li L, Li W, Hou T, Ma H, Yang Y, et al. Impact of Healthcare-Associated Infections on Length of Stay: A Study in 68 Hospitals in China. Biomed Res Int. 2019;2019:2590563-.

7. Aktar F, Tekin R, Güneş A, Ülgen C, Tan I, Ertuğrul S, et al. Determining the Independent Risk Factors and Mortality Rate of Nosocomial Infections in Pediatric Patients. Biomed Res Int. 2016;2016:7240864.

8. Zipursky AR, Yoon EW, Emberley J, Bertelle V, Kanungo J, Lee SK, et al. Central Line-Associated Blood Stream Infections and Non-Central Line-Associated Blood Stream Infections Surveillance in Canadian Tertiary Care Neonatal Intensive Care Units. The Journal of Pediatrics. 2019;208:176 - 82.e6.

9. Wang L, Du K-N, Zhao Y-L, Yu Y-J, Sun L, Jiang H-B. Risk Factors of Nosocomial Infection for Infants in Neonatal Intensive Care Units: A Systematic Review and Meta-Analysis. Med Sci Monit. 2019;25:821320.

10. Zaidi AKM, Huskins WC, Thaver D, Bhutta ZA, Abbas Z, Goldmann DA. Hospital-acquired neonatal infections in developing countries. The Lancet. 2005;365(9465):1175-88. 
11. Wang Z, Xia Z. What we can do? The risk factors for multi-drug resistant infection in pediatric intensive care unit (PICU): a case-control study. Italian Journal of Pediatrics. 2020;46(1):17.

12. Zheng B, Dai Y, Liu Y, Shi W, Dai E, Han Y, et al. Molecular Epidemiology and Risk Factors of Carbapenem-Resistant Klebsiella pneumoniae Infections in Eastern China. Frontiers in microbiology. 2017;8:1061.

13. Umscheid CA, Mitchell MD, Doshi JA, Agarwal R, Williams K, Brennan PJ. Estimating the proportion of healthcare-associated infections that are reasonably preventable and the related mortality and costs. Infection control and hospital epidemiology. 2011;32(2):101-14.

14. de Melo LSW, de Abreu MVM, de Oliveira Santos BR, das Graças Washington Casimiro Carreteiro M, de Souza MFAM, de Albuquerque MCAL, et al. Partnership among hospitals to reduce healthcare associated infections: a quasi-experimental study in Brazilian ICUs. BMC Infectious Diseases. 2021;21(1):212.

15. Vincent JL, Sakr Y, Singer M, Martin-Loeches I, Machado FR, Marshall JC, et al. Prevalence and Outcomes of Infection Among Patients in Intensive Care Units in 2017. Jama. 2020;323(15):1478-87.

16. (CASP) CASP. CASP Checklist 2018 [cited 2021 July 21]. Available from: https://casp-uk.net/casp-toolschecklists/.

17. Wang H. Study on risk factors of healthcare-associated infections in pediatrics department of a general hospital (in Chinese). Anhui: Anhui Medical University; 2008.

18. Qinglin J. Study on risk factors and prevention of healthcare-associated infections among peadiatrics hospitalized patients (in Chinese). Chinese Baby. 2020(9):135.

19. Chen X. Study on risk factors of healthcare-associated infections among patients from pediatrics in a general hospital (in Chinese). Psychological Doctor. 2017;23(28):339-40.

20. Chen Y. The analysis and intervention of hospital acquired infections in children's ward in a general hospital (in Chinese). Nursing and Rehabilitation Journal. 2005;4(2):93-4.

21. Xu Q. Study on risk factors of patients from pediatrics wards in a general hospital (in Chinese). Health Guide. 2018(45):270.

22. Zhao R, Peng Y, Zhou L. Analysis and control strategy on healthcare-associated infections in pediatrics wards of a general hospital (in Chinese). Journal of Clinical Research. 2009;26(5):887-9.

23. Zheng X, ZHao H, Deng H, Wang Y, Xu Y, Yuan X, et al. Risk factors for nosocomial infections in wards of pediatrics in a general hospital (in Chinese). Chinese Journal of Nosocomiology. 2014(10):2543-5.

24. Yang $\mathrm{X}$, Jin J, Jin $\mathrm{O}$, Zhang $\mathrm{H}$, Sheng $\mathrm{H}$. Clinical analysis of nosocomial infections in pediatrics wards of a general hospital (in Chinese). Chinese Journal of Nosocomiology. 2016(4):914-6.

25. Yu H, Shi J, Zhu J, CHen T, Kang J. Investigation of hospital infection in the pediatric department of a general hospital (in Chinese). Chinese Journal of Contemporary Pediatrics. 2006;8(3):242-4.

26. Wei X. Clinical analysis of nosocomial infections in pediatrics department of a general hospital (in Chinese). Chinese Journal of Nosocomiology. 2013;23(5):1080-1.

27. Yanan X. Analysis of characteristics and risk factors of neonatal nosomial infection in intensive care unit (in Chinese). The Medical Forum. 2020;24(3):324-6. 
28. Huang J, Jiao R, Qiu X, Yu X. Investigation and strategy on healthcare-associated infections in pediatrics wards of a general hospital (in Chinese). China Foreign Medical Treatment. 2008;27(14):159-60.

29. Sun X, Ren C, Qiu M. Analysis and control strategy on healthcare-associated infections of patients in pediatrics ward of a general hospital (in Chinese). Chinese Community Doctors. 2012;14(29):152,4.

30. Tan Y. Nosocomial infection in pediatrics wards of general hospital: clinical analysis and prevention (in Chinese). Chinese Journal of Nosocomiology. 2009;19(1):56-8.

31. Zhou Y. Clinical characteristics of nosocomial infection in pediatrics wards of a secondary hospital (in Chinese). Medical Innovation of China. 2018;15(24):120-3.

32. Li L, Tang Y. Analysis on the states of the infection of hospitalized pediatric patients (in Chinese). Laboratory Medicine and Clinic. 2010;7(10):946-7.

33. Smathers S. Non-ventilator health care-associated pneumonia (NV-HAP): Pediatrics. American Journal of Infection Control. 2020;48(5, Supplement):A17-A9.

34. See I, Chang J, Gualandi N, Buser GL, Rohrbach P, Smeltz DA, et al. Clinical Correlates of Surveillance Events Detected by National Healthcare Safety Network Pneumonia and Lower Respiratory Infection Definitions-Pennsylvania, 2011-2012. Infection Control \& Hospital Epidemiology. 2016;37(7):818-24.

35. Mello MJ, Albuquerque Mde F, Lacerda HR, Souza WV, Correia JB, Britto MC. Risk factors for healthcareassociated infection in pediatric intensive care units: a systematic review. Cadernos de saude publica. 2009;25 Suppl 3:S373-91.

36. Netto R, Mondini M, Pezzella C, Romani L, Lucignano B, Pansani L, et al. Parenteral Nutrition Is One of the Most Significant Risk Factors for Nosocomial Infections in a Pediatric Cardiac Intensive Care Unit. JPEN Journal of Parenteral and Enteral Nutrition. 2017;41(4):612-8.

37. Olivier C, Kunneke H, O'Connell N, Von Delft E, Wates M, Dramowski A. Healthcare-associated infections in paediatric and neonatal wards: A point prevalence survey at four South African hospitals. South African Medical Journal. 2018;108(5):418-22.

38. Alqahtani JM. Emergence of Stenotrophomonas maltophilia nosocomial isolates in a Saudi children's hospital. Saudi Medical Journal. 2017;38(5):521-7.

39. Ciofi Degli Atti ML, D'Amore C, Ceradini J, Paolini V, Ciliento G, Chessa G, et al. Prevalence of antibiotic use in a tertiary care hospital in Italy, 2008-2016. Italian Journal of Pediatrics. 2019;45(1):63.

40. Hopmans TEM, Smid EA, Wille JC, van der Kooi TII, Koek MBG, Vos MC, et al. Trends in prevalence of healthcare-associated infections and antimicrobial use in hospitals in the Netherlands: 10 years of national point-prevalence surveys. Journal of Hospital Infection. 2020;104(2):181-7.

\section{Tables}

Table 1 Characteristics of the included studies on risk factors for healthcare-associated infections among paediatric hospitalized patients in Chinese general hospitals from 2001 to 2020 


\begin{tabular}{|c|c|c|c|c|c|c|c|}
\hline \multirow[t]{2}{*}{$\begin{array}{l}\text { Study } \\
\text { ID }\end{array}$} & \multirow[t]{2}{*}{$\begin{array}{l}\text { Author } \\
\text { (Year) }\end{array}$} & \multirow[t]{2}{*}{ Study design } & \multirow[t]{2}{*}{$\begin{array}{l}\text { Region } \\
\text { (Province) }\end{array}$} & \multirow[t]{2}{*}{$\begin{array}{l}\text { Study } \\
\text { setting }\end{array}$} & \multirow{2}{*}{$\begin{array}{l}\text { Year begun } \\
\text { and duration } \\
\text { (years) }\end{array}$} & \multicolumn{2}{|c|}{$\begin{array}{l}\text { Number of } \\
\text { participants }\end{array}$} \\
\hline & & & & & & HAls & $\begin{array}{l}\text { Non- } \\
\text { HAls }\end{array}$ \\
\hline 1 & $\begin{array}{l}\text { Chen } \\
\text { (2017) (19) }\end{array}$ & $\begin{array}{l}\text { Retrospective } \\
\text { Cross-sectional }\end{array}$ & $\begin{array}{l}\text { Neijiang } \\
\text { (Sichuan) }\end{array}$ & $\begin{array}{l}\text { One } \\
\text { tertiary } \\
\text { hospital }\end{array}$ & 2015,1 & 34 & 566 \\
\hline 2 & $\begin{array}{l}\text { Zhou } \\
\text { (2018) (31) }\end{array}$ & $\begin{array}{l}\text { Retrospective } \\
\text { Cross-sectional }\end{array}$ & Beijing & $\begin{array}{l}\text { One } \\
\text { secondary } \\
\text { hospital }\end{array}$ & 2011,5 & 48 & 1,844 \\
\hline 3 & $\begin{array}{l}\mathrm{Xu} \\
(2018)(21)\end{array}$ & $\begin{array}{l}\text { Retrospective } \\
\text { Case-Control }\end{array}$ & $\begin{array}{l}\text { Hangzhou } \\
\text { (Zhejiang) }\end{array}$ & $\begin{array}{l}\text { One } \\
\text { tertiary } \\
\text { hospital }\end{array}$ & 2017,1 & 30 & 30 \\
\hline 4 & $\begin{array}{l}\text { Wei } \\
(2013)(26)\end{array}$ & $\begin{array}{l}\text { Retrospective } \\
\text { Cross-sectional }\end{array}$ & $\begin{array}{l}\text { Yuyao } \\
\text { (Zhejiang) }\end{array}$ & $\begin{array}{l}\text { One } \\
\text { secondary } \\
\text { hospital }\end{array}$ & 2004,8 & 60 & 4,170 \\
\hline 5 & $\begin{array}{l}\text { Yu et al. } \\
(2006)(25)\end{array}$ & $\begin{array}{l}\text { Retrospective } \\
\text { Cohort }\end{array}$ & Shanghai & $\begin{array}{l}\text { One } \\
\text { tertiary } \\
\text { hospital }\end{array}$ & 2003,2 & 850 & 17,811 \\
\hline 6 & $\begin{array}{l}\mathrm{Li} \& \text { Tang } \\
(2010)(32)\end{array}$ & $\begin{array}{l}\text { Retrospective } \\
\text { Cross-sectional }\end{array}$ & $\begin{array}{l}\text { Neijiang } \\
\text { (Sichuan) }\end{array}$ & $\begin{array}{l}\text { One } \\
\text { tertiary } \\
\text { hospital }\end{array}$ & 2008,2 & 125 & 5,183 \\
\hline 7 & $\begin{array}{l}\text { Chen } \\
\text { (2005) (20) }\end{array}$ & $\begin{array}{l}\text { Retrospective } \\
\text { Cross-sectional }\end{array}$ & $\begin{array}{l}\text { Xianju } \\
\text { (Zhejiang) }\end{array}$ & $\begin{array}{l}\text { One } \\
\text { secondary } \\
\text { hospital }\end{array}$ & 2001,3 & 173 & 5,353 \\
\hline 8 & $\begin{array}{l}\text { Zhao } \\
\text { (2009) (22) }\end{array}$ & $\begin{array}{l}\text { Retrospective } \\
\text { Cross-sectional }\end{array}$ & $\begin{array}{l}\text { Changsha } \\
\text { (Hunan) }\end{array}$ & $\begin{array}{l}\text { One } \\
\text { tertiary } \\
\text { hospital }\end{array}$ & 2006,3 & 201 & 4,839 \\
\hline 9 & $\begin{array}{l}\text { Huang et } \\
\text { al. } \\
(2008)(28)\end{array}$ & $\begin{array}{l}\text { Retrospective and } \\
\text { Prospective Cross- } \\
\text { sectional }\end{array}$ & $\begin{array}{l}\text { Fuzhou } \\
\text { (Jiangxi) }\end{array}$ & $\begin{array}{l}\text { One } \\
\text { tertiary } \\
\text { hospital }\end{array}$ & 2005,3 & 305 & 7,374 \\
\hline 10 & $\begin{array}{l}\text { Sun et al. } \\
(2012)(29)\end{array}$ & $\begin{array}{l}\text { Retrospective } \\
\text { Cross-sectional }\end{array}$ & $\begin{array}{l}\text { Wenxi } \\
\text { (Shanxi) }\end{array}$ & $\begin{array}{l}\text { One } \\
\text { secondary } \\
\text { hospital }\end{array}$ & 2008,3 & 165 & 4,649 \\
\hline 11 & $\begin{array}{l}\text { Tan } \\
(2009)(30)\end{array}$ & $\begin{array}{l}\text { Retrospective } \\
\text { Cross-sectional }\end{array}$ & Shanghai & $\begin{array}{l}\text { One } \\
\text { secondary } \\
\text { hospital }\end{array}$ & 2005,2 & 215 & 4,299 \\
\hline 12 & $\begin{array}{l}\text { Wang } \\
(2008)(17)\end{array}$ & $\begin{array}{l}\text { Retrospective } \\
\text { Case-Control }\end{array}$ & $\begin{array}{l}\text { Tongling } \\
\text { (Anhui) }\end{array}$ & $\begin{array}{l}\text { One } \\
\text { tertiary } \\
\text { hospital }\end{array}$ & 2003,3 & 105 & 105 \\
\hline 13 & $\begin{array}{l}\text { Zheng et } \\
\text { al. } \\
(2014)(23)\end{array}$ & $\begin{array}{l}\text { Retrospective } \\
\text { Cross-sectional }\end{array}$ & $\begin{array}{l}\text { Tangshan } \\
\text { (Hebei) }\end{array}$ & $\begin{array}{l}\text { One } \\
\text { tertiary } \\
\text { hospital }\end{array}$ & 2012,1 & 59 & 980 \\
\hline 14 & $\begin{array}{l}\text { Yang et al. } \\
\text { (2016) (24) }\end{array}$ & $\begin{array}{l}\text { Retrospective } \\
\text { Cross-sectional }\end{array}$ & $\begin{array}{l}\text { Wenzhou } \\
\text { (Zhejiang) }\end{array}$ & $\begin{array}{l}\text { One } \\
\text { tertiary } \\
\text { hospital }\end{array}$ & 2010,5 & 56 & 1,944 \\
\hline
\end{tabular}


One

secondary

hospital

2017,2

12

188

Table 2 Frequency of the identified risk factors in the included studies on risk factors for healthcareassociated infections among paediatric hospitalized patients in Chinese general hospitals from 2001 to 2020 


\begin{tabular}{|c|c|c|c|c|c|c|c|c|c|c|c|c|c|c|c|c|}
\hline $\begin{array}{l}\text { Study ID/Risk } \\
\text { factors }\end{array}$ & 1 & 2 & 3 & 4 & 5 & 6 & 7 & 8 & 9 & 10 & 11 & 12 & 13 & 14 & 15 & Total \\
\hline Age & $\sqrt{ }$ & & $\sqrt{ }$ & $\sqrt{ }$ & & $\sqrt{ }$ & $\sqrt{ }$ & $\sqrt{ }$ & & & & $\sqrt{ }$ & $\sqrt{ }$ & $\sqrt{ }$ & $\sqrt{ }$ & 10 \\
\hline Apgar scores & & & & & & & & & & & & $\sqrt{ }$ & & & & 1 \\
\hline Gender & $\sqrt{ }$ & & & & & & $\sqrt{ }$ & & & & & $\sqrt{ }$ & & $\sqrt{ }$ & $\sqrt{ }$ & 5 \\
\hline Hormone & & & & & & & & & & & & $\sqrt{ }$ & & & $\sqrt{ }$ & 2 \\
\hline $\begin{array}{l}\text { Hypoxic- } \\
\text { ischemic } \\
\text { encephalopathy } \\
\text { (HIE) }\end{array}$ & & & & & & & & & & & & $\sqrt{ }$ & & & & 1 \\
\hline $\begin{array}{l}\text { Infection when } \\
\text { admitted }\end{array}$ & & & & & & & & & & & & & & & $\sqrt{ }$ & 1 \\
\hline $\begin{array}{l}\text { Invasive } \\
\text { procedure }\end{array}$ & & & $\sqrt{ }$ & $\sqrt{ }$ & & & & & & & & $\sqrt{ }$ & & & & 3 \\
\hline $\begin{array}{l}\text { Length of } \\
\text { hospitalization }\end{array}$ & $\sqrt{ }$ & $\sqrt{ }$ & $\sqrt{ }$ & $\sqrt{ }$ & & $\sqrt{ }$ & $\sqrt{ }$ & $\sqrt{ }$ & $\sqrt{ }$ & $\sqrt{ }$ & $\sqrt{ }$ & $\sqrt{ }$ & $\sqrt{ }$ & $\sqrt{ }$ & $\sqrt{ }$ & 14 \\
\hline $\begin{array}{l}\text { Length of time } \\
\text { of antibiotics } \\
\text { use }\end{array}$ & & & & & & & & & & & & $\sqrt{ }$ & & & $\sqrt{ }$ & 2 \\
\hline Malnutrition & & & & & & & & & & & & $\sqrt{ }$ & & & $\sqrt{ }$ & 2 \\
\hline $\begin{array}{l}\text { Neonatal } \\
\text { asphyxia }\end{array}$ & & & & & & & & & & & & $\sqrt{ }$ & & & & 1 \\
\hline $\begin{array}{l}\text { Number of } \\
\text { kinds of } \\
\text { antibiotics }\end{array}$ & & $\sqrt{ }$ & & & & $\sqrt{ }$ & $\sqrt{ }$ & & & & & $\sqrt{ }$ & & & $\sqrt{ }$ & 5 \\
\hline $\begin{array}{l}\text { Number of } \\
\text { underlying } \\
\text { disease }\end{array}$ & & $\sqrt{ }$ & $\sqrt{ }$ & & & & & & & & & $\sqrt{ }$ & & & & 3 \\
\hline Pneumonia & & & & & & & & & & & & $\sqrt{ }$ & & & & 1 \\
\hline Premature & & & & & & & & & & & & $\sqrt{ }$ & & & & 1 \\
\hline Room size & $\sqrt{ }$ & & & & & & & & & & & & $\sqrt{ }$ & & & 2 \\
\hline Seasons & $\sqrt{ }$ & & & & $\sqrt{ }$ & $\sqrt{ }$ & & & & & & & $\sqrt{ }$ & & & 4 \\
\hline Stay in ICU & & & & & & & & & & & & $\sqrt{ }$ & & & & 1 \\
\hline $\begin{array}{l}\text { Tracheal } \\
\text { cannula }\end{array}$ & & & & & & & & & & & & & & $\sqrt{ }$ & & 1 \\
\hline $\begin{array}{l}\text { Use of } \\
\text { antibiotics }\end{array}$ & & & $\sqrt{ }$ & $\sqrt{ }$ & & & & & & & & & & $\sqrt{ }$ & & 3 \\
\hline
\end{tabular}

Table 3 The pooled ORs of the risk factors estimated in the meta-analyses between the patients with HAls and the patients without HAls among paediatric hospitalized patients 


\begin{tabular}{|c|c|c|c|c|c|c|c|}
\hline \multirow[t]{2}{*}{ Risk factors } & \multicolumn{2}{|c|}{$\begin{array}{l}\text { Number of } \\
\text { patients }\end{array}$} & \multirow{2}{*}{$\begin{array}{l}\text { Meta- } \\
\text { analysis } \\
\text { model }\end{array}$} & \multirow[t]{2}{*}{$\begin{array}{l}\text { OR }[95 \% \\
\text { CII }\end{array}$} & \multirow[t]{2}{*}{${ }^{2}(P)$} & \multirow[t]{2}{*}{$R(\%)$} & \multirow[t]{2}{*}{$P$-value } \\
\hline & HAls & $\begin{array}{l}\text { Non- } \\
\text { HAls }\end{array}$ & & & & & \\
\hline Age ( $\leq 1$ year vs. $>1$ year) & 602 & 11,873 & $\begin{array}{l}\text { Random- } \\
\text { effects }\end{array}$ & $\begin{array}{l}2.25 \\
{[1.32-} \\
3.85]\end{array}$ & $\begin{array}{l}0.35 \\
(<0.01)\end{array}$ & 84 & $0.003^{*}$ \\
\hline Gender (male vs. female) & 1,258 & 25,453 & $\begin{array}{l}\text { Fixed- } \\
\text { effects }\end{array}$ & $\begin{array}{l}1.07 \\
{[0.95-} \\
1.21]\end{array}$ & - & 0 & 0.26 \\
\hline Hormone & 117 & 293 & $\begin{array}{l}\text { Fixed- } \\
\text { effects }\end{array}$ & $\begin{array}{l}3.66 \\
{[1.73-} \\
7.74]\end{array}$ & - & 0 & $0.0007^{\star}$ \\
\hline Invasive procedure & 117 & 293 & $\begin{array}{l}\text { Fixed- } \\
\text { effects }\end{array}$ & $\begin{array}{l}5.62 \\
{[4.27-} \\
7.40]\end{array}$ & - & 0 & $0.0007^{\star}$ \\
\hline $\begin{array}{l}\text { Length of hospitalization } \\
\text { ( } \geq 7 \text { days vs. }<7 \text { days) }\end{array}$ & 2,241 & 49,794 & $\begin{array}{l}\text { Random- } \\
\text { effects }\end{array}$ & $\begin{array}{l}7.79 \\
{[6.38-} \\
9.50]\end{array}$ & $\begin{array}{l}0.06 \\
(0.001)\end{array}$ & 64 & $<0.01^{*}$ \\
\hline Malnutrition & 59 & 235 & $\begin{array}{l}\text { Fixed- } \\
\text { effects }\end{array}$ & $\begin{array}{l}3.72 \\
{[1.80-} \\
7.70]\end{array}$ & - & 0 & $0.0004^{\star}$ \\
\hline $\begin{array}{l}\text { Number of kinds of } \\
\text { antibiotics ( }>3 \text { vs. } \leq 3)\end{array}$ & 844 & 19,703 & $\begin{array}{l}\text { Fixed- } \\
\text { effects }\end{array}$ & $\begin{array}{l}3.25 \\
{[2.66-} \\
3.96]\end{array}$ & - & 39 & $<0.01^{\star}$ \\
\hline $\begin{array}{l}\text { Number of underlying } \\
\text { disease (>3 vs. } \leq 3 \text { ) }\end{array}$ & 183 & 1,979 & $\begin{array}{l}\text { Random- } \\
\text { effects }\end{array}$ & $\begin{array}{l}4.24 \\
{[1.84-} \\
9.78]\end{array}$ & $\begin{array}{l}0.30 \\
(0.11)\end{array}$ & 55 & $0.0007^{\star}$ \\
\hline Room size (large vs. small) & 93 & 1,546 & $\begin{array}{l}\text { Fixed- } \\
\text { effects }\end{array}$ & $\begin{array}{l}2.22 \\
{[1.28-} \\
3.85]\end{array}$ & - & 0 & $0.005^{\star}$ \\
\hline $\begin{array}{l}\text { Seasons (Autumn + Winter } \\
\text { vs. Spring + Summer) }\end{array}$ & 391 & 12,082 & $\begin{array}{l}\text { Random- } \\
\text { effects }\end{array}$ & $\begin{array}{l}1.56 \\
{[1.04-} \\
2.35]\end{array}$ & $\begin{array}{l}0.11 \\
(0.02)\end{array}$ & 69 & $0.03^{*}$ \\
\hline Use of antibiotics & 843 & 25,524 & $\begin{array}{l}\text { Random- } \\
\text { effects }\end{array}$ & $\begin{array}{l}3.18 \\
{[0.83-} \\
12.15]\end{array}$ & $\begin{array}{l}1.87 \\
(0.01)\end{array}$ & 85 & 0.09 \\
\hline
\end{tabular}

Note: * means the statistical significance at $P<0.05$.

\section{Figures}




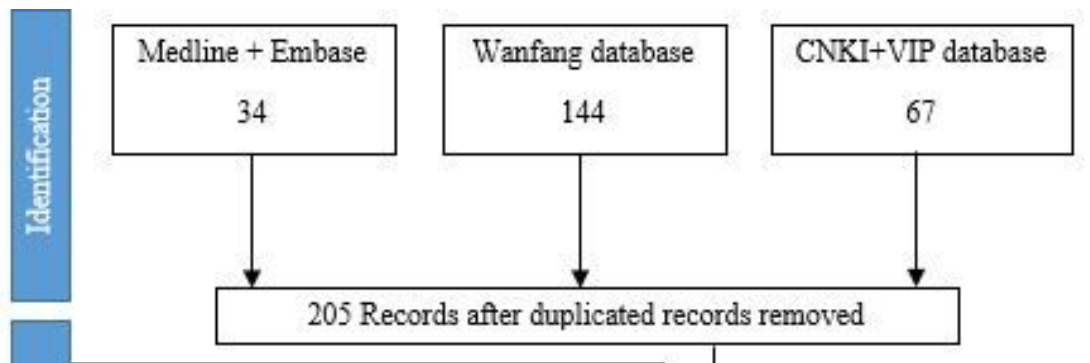

81 records excluded which were irrelevant of risk factors associated with HAIs prevalence among paediatric hospitalised patients after screening the titles, abstracts and keywords

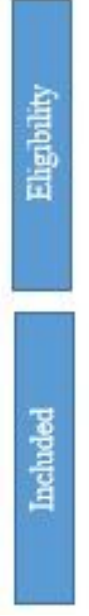

80 Records screened

15 Full-text articles assessed for eligibility

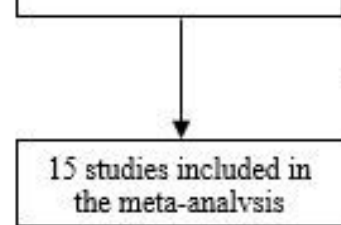

65 records excluded because of:

Studies on specific disease, unit, microorganism or patients $(\mathrm{N}=40)$

Not general hospital or not stating the type of the study hospital $(\mathrm{N}=3)$

Only description on the prevalence or landscape of HAIs or risk factors on HAIs for the overall hospitalised patients $(\mathrm{N}=10)$

Risk factors concluded without any statistical inference and only with description; or using the inappropriate statistical analysis $(\mathrm{N}=12$ )

\section{Figure 1}

Flow diagram of literatures search from the databases Note: Abbreviations: CNKI: China National Knowledge Infrastructure; Wangfang database: Chinese Wan Fang digital database; VIP: Chinese Science and Technique Journals Database; HAls: Healthcare-associated infections.

\section{Supplementary Files}

This is a list of supplementary files associated with this preprint. Click to download.

- Supplementarymaterial.docx 